Journal of Educational

and Psychological Sciences

Volume (4), Issue (47) : 30 Dec 2020

P: 154 - 171

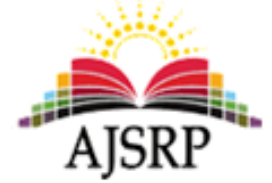

ISSN: 2522-3399

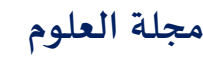

التربوية والنفسية

المجلد (4)، العدد (47) : 30 ديسمبر 2020 م

ص: 154 - 171

\title{
Covid-19 and Its Relationship to the Application of Distance Education in Teaching Social Studies Curriculum for the Upper Basic Stage from the Teachers' Point of View
}

\section{Adnan Mohammad Alnwairan \\ Salsabil Adeeb Hassan}

Faculty of Education || Alyarmouk University || Jordan

\begin{abstract}
This study aimed to identify Covid-19 and its relationship to the application of distance education in teaching social studies curriculum for the upper basic stage from the teachers' point of view. The study has used the descriptiveanalytical approach, where a questionnaire was employed as the study instrument. The population of the study consisted of a random sample from (311) Social studies teachers. The tool was distributed electronically through the use of social media and email to Social studies teachers of upper basic stage in public schools in three governorates, Amman, Salt and Irbid. The results showed that the impact of COVID-19 on teaching social studies curriculum for the upper basic stage was moderate. Furthermore, the level of applying distance education when teaching the social studies curriculum to the upper basic stage from the Teachers' Point of view was moderate as well. The results also showed that there is a significant relation between COVID-19 and the level of distance education application when teaching the social studies curriculum for the upper basic stage. The current study recommends going beyond the schools' scope and researches higher education from across the entire Hashemite Kingdom of Jordan as a follow-up to this research's findings. Further qualitative research would be needed in the future to accurately assert the level of applying distance education
\end{abstract}

Keywords: COVID-19, Social studies, Distance Education, Upper Basic Stage.

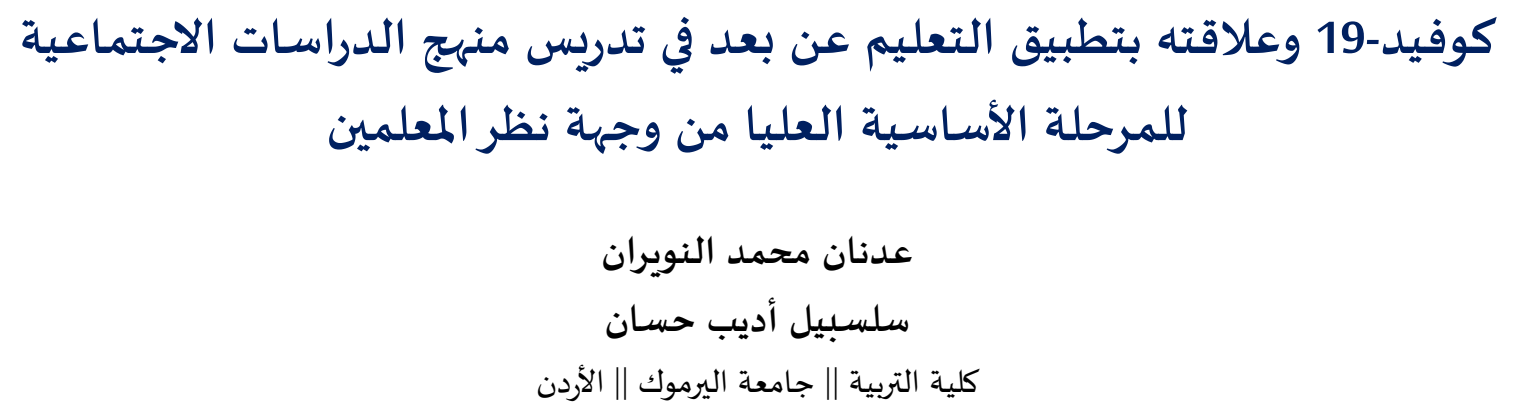

\footnotetext{
الملخص: هدفت هذه الدراسة التعرف إلى كوفيد-19 وعلاقته بتطبيق التعليم عن بعد في تدريس منهج التربية الاجتماعية والوطنية للمرحلة الأساسية العليا من وجهة نظرف المعلمين. استخدمت الدراسة المنهج الوصفي التحليلي، حيث تم استخدام الاستبيان كأداة

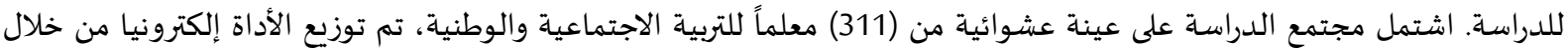
استخدام وسائل التواصل الاجتماعي والبريد الإلكتروني لمعلمي مبحث التربية الاجتماعية والوطنية للمرحلة الأساسية العليا في المدارس مئس

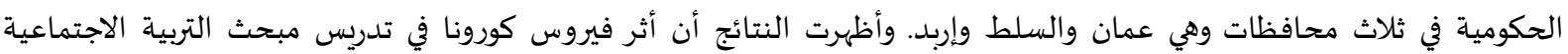
والوطنية للمرحلة الأسـاسية العليا من وجهاة نظر المعلمين جاء بدرجة معتدلة، وأن مستوى تطبيق التعليم عن بعد عند تدريكا تدريس مبحث

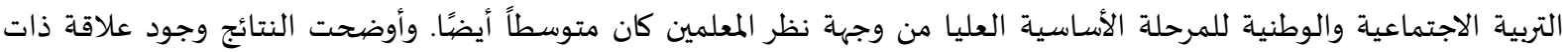




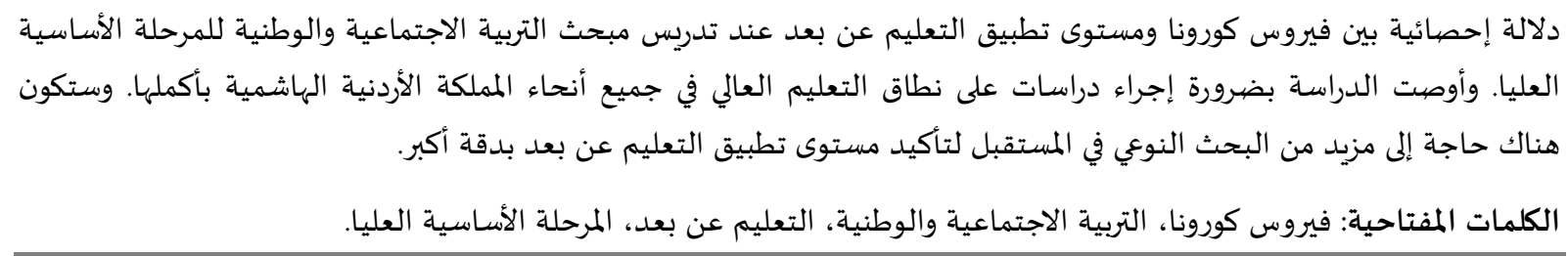

\section{1- Introduction}

In late 2019 until now, the world has witnessed a great event whose effects have been reflected in all aspects of life in the world (Montacute, 2020). One of this aspect is the education domain, but it was one of the sectors most affected by this crisis. In light of the speed and magnitude of the educational disorder resulting from the closure of schools and universities to avoid the spread of the virus among its students, governments seek to provide a new educational technique to reduce the numbers of students affected by the closure of schools and universities (Burgess \& Sievertsen, 2020).

School closures in response to COVID-19 have raised on numerous social and economic issues, such as student debt, digital learning, as well as internet access, and disability services (Reimers \& Schleicher, 2020). In April 2020, approximately (1.723) billion pupils have been influenced for school closures in response to the crisis. The impact was more extreme for disadvantaged students, causing interrupted learning, denying them their right to complete their education (Coibion, Gorodnichenko, \& Weber, 2020). In response to school closures, The Ministry of Education in many countries recommended the use of distance learning programs and open educational and platforms that schools and teachers can use to reach students remotely and limit the disruption of education (Helmich, \& Bloem, 2020).

Distance education is an educational strategy that helps students receive their education without being physically present at school. In other words, the student can learn and qualify in educational materials online without having to attend the examination centre, college building, or university campus (Tavukcu, Arapa \& Özcan, 2011). According to Petsuwan, Pimdee \& Pupat (2019), the idea of distance education today is based on the use of the Internet and is now readily available to the vast majority of students either in their homes or in facilities such as local libraries. These electronic means are used to distribute learning materials, to keep students in contact with teachers, and to provide access to communication between students. Of course, distance learning can use other technological formats, including television, DVDs, teleconferencing and printable materials, but the speed and functionality of online learning have made it the first choice for many distance learners. Online programs often take advantage of several emerging technologies to make effective communication and communication of ideas easier and more efficient than ever before allowing students to share their opinions and express them more easily (Gossenheimer, Bem, Carneiro \& de Castro, 2017).

Research has identified that distance learning of Social Education courses was initially designed to support educational opportunities for students who were limited by geographical location or lifestyle to 
attend the face-to-face educational preparation (Zhang, Burgos \& Dawson, 2019). Online learning tools provide the flexibility and opportunity to complete course requirements from almost anywhere. According to Rundle, Park, Herbstman, Kinsey \& Wang (2020), the increased ease of communication between participants, more equal participation in a discussion, the anonymity of participants, reduced bias, and the ability to tackle more controversial topics are some of the advantages of distance education.

\section{Problem Statement}

In light of the circumstances that affect the spread of the COVID-19, which has swept the whole world, the distance education process has been activated in Jordan, stopping students from attending schools within and achieving precautionary measures to achieve social divergence to prevent the spread of the virus. The Jordanian government was able to activate an alternative that simulates the current crisis through TV channels and electronic platforms, the most famous of which is your educational lesson platform that broadcasts TV lessons via Jordan Sports Channel and is repeated regularly. However, many students did not have the opportunity to participate in this process because of the weak internet speed, and there are no adequate devices to complete this process, which contributed to weakening their ability to acquire new skills and experiences. Hence, the problem of the study came in answering the following questions:

- What is the impact of COVID-19 on teaching social studies curriculum for the upper basic stage from the teachers' point of view?

- What is the level of applying distance education when teaching the social studies curriculum to the upper basic stage from the Teachers' Point of view?

- Is there a correlation between COVID-19 and the level of distance education application when teaching the social studies curriculum for the upper basic stage?

\section{Procedural definitions of the terms}

COVID-19: a large group of viruses that can cause a range of diseases, ranging from a common cold to severe acute respiratory syndrome (SARS). The resulting disease is called Coronavirus 2019 (COVID-19). (Keeling, Hollingsworth \& Read, 2020).

Social studies: The Integrated Study of Social Sciences and Humanities to enhance civic competence. Social studies mainly seek to provide citizens with knowledge about the world, the nation, and the society around them by helping other disciplines such as political science, history, economics, religion, geography, anthropology, as well as psychology (Topçu, 2017).

Distance Education: An educational system based on the idea of communicating new concepts and knowledge in the learning materials of the learner through modern technological means of communication, where the student is far and separate from the teacher. This type of learning occurs when 
the natural distance between the learner and the teacher is separated during the learning process (Petsuwan, Pimdee \& Pupat, 2019).

\section{Study Limits}

- Time Limitation: the study is limited to the second semester of the academic year (2019/2020)

- Place Limitation: the study is limited to public schools in three governorates, Amman, Salt and Irbid.

- Individual Limitation: the study is limited to Teachers of social studies for the upper basic stage.

\section{Literature review}

\subsection{COVID-19es (COVID-19)}

COVID-19es are a wide range of viruses that may cause disease in animals and humans. It is known that several COVID-19es cause human respiratory diseases in severity ranging from the common cold to more severe diseases such as Middle East Respiratory Syndrome (MERS) and Severe Acute Respiratory Syndrome (SARS). The newly discovered COVID-19 causes Covid-19 disease (Di Domenico, Pullano, Sabbatini, Boëlle, \& Colizza. 2020).

The Covid-19 disease is an infectious disease caused by the last detected virus of the COVID-19. There was no knowledge of this new virus and its disease before it began spreading in Wuhan, China, in December (2019). Covid-19 has now turned into a pandemic affecting many countries of the world (Coibion, Gorodnichenko \& Weber, 2020). The most known symptoms of Covid-19 disease are fever, fatigue, and dry cough. Some people become infected without feeling very mild symptoms (Lee, I., Kovarik, Tejasvi, Pizarro \& Lipoff, 2020).

The COVID-19 pandemic has influenced educational policies worldwide as well, leading many countries to close the schools, universities and colleges, Education institution leaders have proposed alternative approaches for students and teachers to continue their lessons and provide a safe learning environment (Montacute, 2020).

According to data released by UNESCO, the crisis is now affecting nearly (363) million learners worldwide, from pre-primary to higher education, including (57.8) million students in higher education. One out of every five students worldwide fails to study due to the COVID-19 crisis, and one out of every four students remains outside of higher education institutions (UNESCO, 2020).

To ensure that educational systems respond appropriately, the United Nations Educational, Scientific and Cultural Organization (UNESCO) recommends that countries "work to find solutions based on advanced or simple technology or without using technology to ensure the consistency and continuity of the learning process (UNESCO, 2020). In many countries, teachers originally use online learning platforms to give homework to supplement their regular classroom hours of communication and to give class exercises and research. Many students can use technology devices at home (Setiawan, 2020). 


\subsection{Distance Teaching of Social Studies}

Distance education has a long tradition and has been separated from school-based education. Distance education focuses on providing curricula that allow access to education and training, freeing students and teachers from the constraints of time and space, and providing them with flexible learning opportunities (Erickson \& Larwin, 2016).

Zhang, Burgos \& Dawson (2019) have defined distance learning as an educational system based on the idea of delivering the educational material to the learner through the various technical communication means, as the student is away and separate from the teacher. This type of learning takes place when the normal distance between the learner and the teacher separates during the learning process (Gossenheimer, Bem, Carneiro \& de Castro, 2017).

Many of the teachers of social studies have sought to achieve distance education through Instructional Design, to prepare an educational material that achieves the goals with high efficiency. This design is generally based on studying the educational needs of students, setting goals and appropriate means to achieve them, and tools for measuring learning and feedback (Zhang, Burgos \& Dawson, 2019).

Distance social studies education provides opportunities for students to develop attitudes, skills, and knowledge that enable them to become active and responsible citizens of their community while they are in their places of residence. Recognition and respect of individual and collective identity are essential in a pluralistic and democratic society (Gossenheimer, Bem, Carneiro \& de Castro, 2017). Social studies help students develop their sense of self and society, which encourages them to assert their place as citizens of an inclusive democratic society (Erickson \& Larwin, 2016).

There is a set of requirements that must be met when Social studies Curriculum is taught remotely. (Zhang, Burgos \& Dawson, 2019) Indicated that one of the most important (1) is the preparation of materials; (2) To manage the dissemination and exchange of information by technological means; And (3) the continuous development of course work and the professional development of teachers in the use of technology in education (Madge et al., 2019).

Setiawan (2020) states that coronavirus (COVID-19) contributed to promoting distance education of social studies during the last period. Teachers work tirelessly to find solutions for distance learning, especially with each school needing to provide educational solutions appropriate for the ages of its pupils, to provide appropriate content for distance learning and to maintain communication with its students (Bozkurt, Zawacki-Richter, \& Aydin, 2019).

There are difficulties facing distance education social studies such as the weak capabilities of students and students, whether the Internet is weak or the absence of modern technological means or residency in areas with poor coverage. The lack of student attendance at classes is another challenge that the distance learning system faces (Chugh, Ledger, \& Shields, 2017). 
Setiawan (2020) added that teachers must know the conditions of all their students to choose the most appropriate methods for the group. It may also be better to reduce the use of video in face-to-face meetings or use it for a short time so that all challenges facing the teacher and the student alike are overcome.

\subsection{Previous Studies}

Chen, Ran, Liu, Hu, Du \& Tan (2020) conducted a study aimed to identify the status of hand hygiene and mask-wearing among primary school students in Wuhan, China during the COVID-19 pandemic. A descriptive-analytical approach was used. The study sample consisted of (576) students from 15 primary schools in Wuhan, China. The results showed that (42.05\%) of the primary school students showed good behaviour of hand-washing, while $(51.60 \%)$ had a good behaviour of mask-wearing. Gender, grade, out-going history, father's occupation, mother's educational background, and the time filling out the survey were significantly associated with hand hygiene, whereas grade, mother's educational background, and residence were associated with mask-wearing.

Gao (2020) conducted a study aimed to explore the impact new mode of distance learning in primary schools in the environment of multimedia computer-assisted instruction. An analytical approach was used. The results revealed that the application of multimedia technology and distance education in Chinese education in primary schools greatly enhance Chinese teaching and respond to the requirements of national education reform. Distance education and the introduction of new techniques in education contribute to improving the effectiveness of teaching and the quality of teaching.

Burdina, Krapotkina, \& Nasyrova (2019) conducted a study aimed at investigating the effect of distance learning in elementary school classrooms as an emerging framework for contemporary practice. The sample consisted of (430) students aged 8-9 years from across the Republic of Tatarstan. The results showed that the distance learning curriculum in primary schools requires an amendment, as students need a teacher who directs them to obtain better degrees. Student-teacher communication can help students increase their academic performance and motivate them.

McKay (2019) conducted a study aimed to identify the impact of using a distance education approach to support underperforming schools in South Africa. A descriptive-analytical approach was used. The study sample consisted of (969) teachers, (455) learners, (337) heads of department and (269) school governing body representatives and parent focus groups. The results showed that distance education was an attractive idea, and students were excited to use it. Furthermore, the use of distance education contributed to improving students' performance and their acquisition of new concepts more easily and quickly. 


\section{RESEARCH METHODOLOGY}

\subsection{The Research Instrument}

The instrument contains (25) items. The questionnaire was distributed by emails and social media means.

The questionnaire contains (3) demographic variables and (25) questions represent study variables like the following:

\subsection{Variables:}

First Axis: COVID-19 with a total of (10) questions:

Second Axis: Distance Education Application formulated into benchmarks or objectives to reach, into (3) fields with a total of (15) questions

- The level of distance education application related to Teachers: contains (5) questions.

- The level of distance education application related to Students: contains (5) questions.

- The level of distance education application related to organizational and technical matters: contains (5) questions.

\subsection{Data Analysis and Interpretation}

To examine the Impact of COVID-19 on Teaching Social studies curriculum in Distance Education for the Upper Basic Stage from the Teachers' Point of view. Statistical Package for Social Sciences (SPSS) will be used in processing the following statistical techniques and tests in data analysis:

1. Reliability Test for the Instruments of Measurement. The reliability of a measure highlights the stability of consistency with which the instrument is measuring the concept and helps to assess the 'goodness' of a measure.

2. Frequencies and percentages to describe demographical variables.

3. Descriptive Statistical Techniques: these included means and standard deviations. These techniques will be used to illustrate respondents to study fields.

4. Pearson Correlations Coefficients to test the correlations between COVID-19 and the level of distance education application when teaching the social studies curriculum for the upper basic stage explore the direct effects of variables on dependent variables

Respondents were asked to read each item, and select one of the choices as follow:

- Score 5: For the (Strongly Agree Answer)

- Score 4: For the (Agree Answer)

- Score 3: For the (Nuetral Answer)

- Score 2: For the (Disagree Answer) 
- Score 1: For the (Strongly Disagree Answer)

So it divided into three stages as (1.33 is the length of each stage:

- High: For means (1-2.33)

- Moderate: For means (2.34-3.67)

- Low: For means (3.68-5)

\subsection{Study Sample:}

The population of the study consisted of a random sample from (311) Social studies teachers. The tool was distributed electronically through the use of social media and email to Social studies teachers of upper basic stage in public schools in three governorates, Amman, Salt and Irbid, as it is classified into its demographic characteristics in the tables below:

Table (1) Demographic characteristics for the study sample (Gender)

\begin{tabular}{|c|c|c|}
\hline \multirow{2}{*}{ Gender } & \multicolumn{2}{|c|}{ Sample } \\
\cline { 2 - 3 } & Frequency & Percentage \\
\hline Male & 105 & 33.8 \\
\hline Female & 206 & 66.2 \\
\hline \hline Total & 311 & $100 \%$ \\
\hline
\end{tabular}

From the table (1) it shows that the percentage of males from the Sample was (33.8\%) meanwhile it was for females (66.2\%).

Table (2) Demographic Characteristics of the Sample (Academic level)

\begin{tabular}{|c|c|c|}
\hline Academic level & \multicolumn{2}{|c|}{ Sample } \\
\hline Bachelor's Degree & Frequency & $\mathbf{8 0 . 1}$ \\
\hline Master's Degree & 249 & 16.7 \\
\hline Doctorate Degree & 52 & 3.2 \\
\hline \hline Total & 10 & $100.0 \%$ \\
\hline
\end{tabular}

For the variable (Academic level) it seems that the (Bachelor's Degree) rank achieved (80.1\%) and (Master's Degree) rank achieved (16.7\%) and (Doctorate Degree) rank achieved (3.2\%).

Table (3) Demographic Characteristics of the Sample (Years of experience)

\begin{tabular}{|c|c|c|}
\hline \multirow{2}{*}{ Years of experience } & \multicolumn{2}{|c|}{ Sample } \\
\cline { 2 - 3 } Less than 1 year & Frequency & 21.9 \\
\hline $1-3$ years & 68 & 44.6 \\
\hline 3-5 years & 139 & 20.6 \\
\hline More than 5 years & 64 & 12.9 \\
\hline Total & 40 & $100.0 \%$ \\
\hline
\end{tabular}


For the Companies Years of experience, it seems that for (Less than 1 year) percent was (21.9\%) and for (1-3 years) the percent was (44.6\%) and for (3-5 years) the percent was (20.6\%) and for (More than 5 years) the percent was (12.9\%).

\subsection{The validity of the instruments}

The test gave to experts to judge the extent to which the test is valid and reliable. For this reason, the test would be designed to meet such requirements of the validity of the test. The experts will be chosen according to their broad experiences in the field of teaching translation

\subsection{Tool reliability:}

To reach a degree of reliability of the test, the researcher used to test and retest to a different group of students. The test and retest had the same characteristics, to compare if the students achieve stability.

Table (4) Cronbach's alpha for the study fields'

\begin{tabular}{|c|c|c|}
\hline number & Field & Value of $(\alpha)$ \\
\hline 1 & $\begin{array}{l}\text { Impact of COVID-19 on Teaching Social studies curriculum for the upper } \\
\text { basic stage }\end{array}$ & 0.849 \\
\hline 2 & The level of distance education application related to Teachers & 0.816 \\
\hline 3 & The level of distance education application related to Students & 0.752 \\
\hline 4 & $\begin{array}{l}\text { The level of distance education application related to organizational and } \\
\text { technical matters }\end{array}$ & 0.846 \\
\hline
\end{tabular}

As shown from the table above that the total Cronbach's alpha For the study fields was above than (0.60) which will lead to the stability of the results for this study

\section{Study Results}

To analyze the data and answer questions, to explore Impact of COVID-19 on Teaching Social studies curriculum in Distance Education for the Upper Basic Stage from the Teachers' Point of view, Simple, Regression was used as it is shown as follow:

"What is The Impact of COVID-19 on Teaching Social studies curriculum for the upper basic stage from the Teachers' Point of view?"

Means and standard deviation were calculated for each item in the impact of COVID-19 on Teaching Social studies curriculum for the upper basic stage and Table (5) shows the results: 
Table (5) Descriptive Statistics for Impact of COVID-19 on Teaching Social studies curriculum for the upper basic stage

\begin{tabular}{|c|c|c|c|c|c|}
\hline $\begin{array}{l}\text { Question } \\
\text { number }\end{array}$ & Question & Mean & $\begin{array}{l}\text { Std. } \\
\text { Deviation }\end{array}$ & Rank & Level \\
\hline 9 & $\begin{array}{l}\text { I think that the spread of the COVID-19 has added to my } \\
\text { tasks when explaining social studies topics. }\end{array}$ & 3.99 & 0.91 & 1 & High \\
\hline 6 & $\begin{array}{l}\text { I believe that the spread of the COVID-19 has contributed } \\
\text { to a high dropout rate for students from schools. }\end{array}$ & 3.94 & 0.95 & 2 & High \\
\hline 4 & $\begin{array}{l}\text { I believe that the spread of COVID-19 has increased the } \\
\text { interest of my students in Arab and international issues } \\
\text { and events. }\end{array}$ & 3.88 & 1.03 & 3 & High \\
\hline 1 & $\begin{array}{l}\text { I think that closing schools due to COVID-19 have } \\
\text { weakened my ability to deliver students' social and } \\
\text { national concepts. }\end{array}$ & 3.4 & 0.71 & 4 & Moderate \\
\hline 5 & $\begin{array}{l}\text { I think that the closure of schools due to the COVID-19 } \\
\text { pandemic has prevented some students from obtaining } \\
\text { their education in social studies subjects. }\end{array}$ & 3.69 & 0.87 & 5 & Moderate \\
\hline 8 & $\begin{array}{l}\text { I believe that the spread of the COVID-19 highlights some } \\
\text { social issues such as (unemployment, family income, and } \\
\text { the level of parental education). }\end{array}$ & 3.65 & 0.95 & 6 & Moderate \\
\hline 3 & $\begin{array}{l}\text { I see that the spread of COVID-19 has increased student } \\
\text { participation during the lesson explanation }\end{array}$ & 3.62 & 0.81 & 7 & Moderate \\
\hline 7 & $\begin{array}{l}\text { I think the school's closure due to the spread of the COVID- } \\
19 \text { has negatively affected the results of student learning in } \\
\text { the subject of social studies. }\end{array}$ & 3.52 & 0.74 & 8 & Moderate \\
\hline 2 & $\begin{array}{l}\text { The spread of COVID-19 contributed to the use of novel } \\
\text { methods to explain social studies lessons. }\end{array}$ & 3.5 & 0.74 & 9 & Moderate \\
\hline \multirow[t]{2}{*}{10} & $\begin{array}{l}\text { I think that the spread of the COVID-19 has reduced my } \\
\text { ability to assess students as required. }\end{array}$ & 3.4 & 0.71 & 10 & Moderate \\
\hline & $\begin{array}{l}\text { Impact of COVID-19 on Teaching Social studies curriculum } \\
\text { for the upper basic stage }\end{array}$ & 3.66 & 0.59 & & Moderate \\
\hline
\end{tabular}

As it has seen from the above table the total mean for this field was (3.65) and with a standard deviation (0.59), we also note that the question (9) which is "I think that the spread of the COVID-19 has added to my tasks when explaining social studies topics." Ranked first with a mean reached to (3.99) and standard deviation reached to (0.91) and the question (10) which is I think that the spread of the COVID19 has reduced my ability to assess students as required." with mean reached (3.40) and standard deviation reached (0.71) came in the final rank. This may be attributed to the fact that the spread of the Corona Virus (Covid-19) pandemic prompted most schools to choose other ways to complete the 
educational process, but many schools have not previously tested the techniques provided by e-learning, and the experiences of social studies teachers are still very modest and fragile.

What is the level of applying distance education when teaching the social studies curriculum to the upper basic stage from the Teachers' Point of view?

Means and standard deviation were calculated for each field in the study instrument and Table (6) shows the results:

Table (6) Descriptive Statistics for the level of applying distance education when teaching the social studies curriculum to the upper basic stage

\begin{tabular}{|c|c|c|c|c|}
\hline \multirow{2}{*}{$\begin{array}{c}\text { field } \\
\text { number }\end{array}$} & \multicolumn{1}{|c|}{ Field } & $\begin{array}{c}\text { Std. } \\
\text { Deviation }\end{array}$ & Level \\
\hline F1 & The level of distance education application related \\
to Teachers & 3.73 & 0.61 & High \\
\hline F2 & $\begin{array}{r}\text { The level of distance education application related } \\
\text { to Students }\end{array}$ & 3.72 & 0.74 & High \\
\hline F3 & $\begin{array}{r}\text { The level of distance education application related } \\
\text { to organizational and technical matters }\end{array}$ & 3.63 & 0.65 & Moderate \\
\hline \hline & level of applying distance education & 3.69 & 0.58 & Moderate \\
\hline
\end{tabular}

As it is seen from the above table that The level of distance education application related to Teachers field achieved mean which reached (3.73) and a standard deviation (0.61), and The level of distance education application related to Students field achieved mean which reached (3.72) and a standard deviation (0.74), and The level of distance education application related to organizational and technical matters field achieved mean which reached (3.63), and a standard deviation (0.65).

\section{The level of distance education application related to Teachers}

Means and standard deviation were calculated for each item in the level of distance education application related to Teachers and Table (7) shows the results:

Table (7) Descriptive Statistics for the level of distance education application related to Teachers

\begin{tabular}{|c|c|c|c|c|c|}
\hline $\begin{array}{c}\text { Question } \\
\text { number }\end{array}$ & \multicolumn{2}{|c|}{$\begin{array}{c}\text { Question } \\
\text { Q }\end{array}$} & $\begin{array}{c}\text { Mean } \\
\text { Deviation }\end{array}$ & Rank & Level \\
\hline 11 & $\begin{array}{r}\text { I use electronic programs in preparing the study } \\
\text { plan }\end{array}$ & 3.94 & 0.94 & 1 & High \\
\hline 13 & $\begin{array}{r}\text { I use e-mail to communicate with students and } \\
\text { follow their educational duties. }\end{array}$ & 3.89 & 1.02 & 2 & High \\
\hline 14 & $\begin{array}{r}\text { I used electronic maps to explain natural } \\
\text { geography because it shows the facts of nature }\end{array}$ & 3.69 & 0.87 & 3 & High \\
\hline
\end{tabular}




\begin{tabular}{|c|c|c|c|c|c|}
\hline $\begin{array}{l}\text { Question } \\
\text { number }\end{array}$ & Question & Mean & $\begin{array}{c}\text { Std. } \\
\text { Deviation }\end{array}$ & Rank & Level \\
\hline & more accurately & & & & \\
\hline 12 & $\begin{array}{l}\text { I use multimedia software (PowerPoint) to } \\
\text { present social studies topics }\end{array}$ & 3.62 & 0.81 & 4 & Moderate \\
\hline \multirow[t]{2}{*}{15} & $\begin{array}{l}\text { I try to diversify into using multimedia (audio, } \\
\text { photo, video) when explaining issues of } \\
\text { difference between other cultures }\end{array}$ & 3.5 & 0.74 & 5 & Moderate \\
\hline & $\begin{array}{l}\text { The level of distance education application } \\
\text { related to Teacher }\end{array}$ & 3.73 & 0.61 & & High \\
\hline
\end{tabular}

As it has seen from the above table the total mean for this field was (3.73) and with a standard deviation (0.61), we also note that the question (11) which is "I use electronic programs in preparing the study plan" Ranked first with a mean reached to (3.94) and standard deviation reached to (0.94) and the question (15) which is I try to diversify into using multimedia (audio, photo, video) when explaining issues of difference between other cultures." with mean reached (3.50) and standard deviation reached (0.74) came in the final rank. This may be attributed to the fact that the Ministry of Education supported teachers by implementing new interventions to facilitate the transition to distance learning. In addition, the Ministry has launched a newly trained teacher platform to provide training courses on distance learning tools, mixed learning, and educational technology.

\section{The level of distance education application related to Students}

Means and standard deviation were calculated for each item in the level of distance education application related to students and Table (8) shows the results:

Table (8) Descriptive Statistics for the level of distance education application related to Students

\begin{tabular}{|c|c|c|c|c|c|}
\hline $\begin{array}{l}\text { Question } \\
\text { number }\end{array}$ & Question & Mean & $\begin{array}{c}\text { Std. } \\
\text { Deviation }\end{array}$ & Rank & Level \\
\hline 17 & $\begin{array}{l}\text { Using globes and electronic graphs helps } \\
\text { students to understand natural and human } \\
\text { phenomena better. }\end{array}$ & 3.81 & 0.95 & 1 & High \\
\hline 18 & $\begin{array}{l}\text { The display of electronic content coupled with } \\
\text { photos and videos attracts students to learn } \\
\text { better. }\end{array}$ & 3.73 & 0.75 & 2 & High \\
\hline 20 & $\begin{array}{l}\text { Distance education enables students to learn } \\
\text { difficult geographical concepts without getting } \\
\text { bored. }\end{array}$ & 3.71 & 0.81 & 3 & High \\
\hline
\end{tabular}




\begin{tabular}{|c|c|c|c|c|c|}
\hline $\begin{array}{l}\text { Question } \\
\text { number }\end{array}$ & Question & Mean & $\begin{array}{c}\text { Std. } \\
\text { Deviation }\end{array}$ & Rank & Level \\
\hline 16 & $\begin{array}{l}\text { Distance learning helps flexibility in getting } \\
\text { students to access the educational material } \\
\text { from anywhere }\end{array}$ & 3.70 & 0.79 & 4 & High \\
\hline \multirow[t]{2}{*}{19} & $\begin{array}{c}\text { Distance education helps students organize } \\
\text { their time better. }\end{array}$ & 3.62 & 0.81 & 5 & Moderate \\
\hline & $\begin{array}{l}\text { level of distance education application related } \\
\text { to students }\end{array}$ & 3.72 & 0.74 & & High \\
\hline
\end{tabular}

As it has seen from the above table the total mean for this field was (3.72) and with a standard deviation (0.74), we also note that the question (17) which is Using globes and electronic graphs helps students to understand natural and human phenomena better." Ranked first with a mean reached to (3.81) and standard deviation reached to (0.95) and the question (19) which is Distance education helps students organize their time better." with mean reached (3.62) and standard deviation reached (0.81) came in the final rank. This may be due to the fact that teachers have played a critical role in monitoring and enhancing student engagement with digital learning materials.

\section{The level of distance education application related to organizational and technical matters}

Means and standard deviation were calculated for each item in the level of distance education application related to organizational and technical matters and Table (9) shows the results:

Table (9) Descriptive Statistics for the level of distance education application related to organizational and technical matters

\begin{tabular}{|c|c|c|c|c|c|}
\hline $\begin{array}{l}\text { Question } \\
\text { number }\end{array}$ & Question & Mean & $\begin{array}{c}\text { Std. } \\
\text { Deviation }\end{array}$ & Rank & Level \\
\hline 21 & $\begin{array}{l}\text { The school's educational platform provides } \\
\text { support and assistance for distance education }\end{array}$ & 4.01 & 0.92 & 1 & High \\
\hline 23 & $\begin{array}{l}\text { All students have the ability to own a computer } \\
\text { at home for use in a distance education }\end{array}$ & 3.69 & 0.87 & 2 & High \\
\hline 25 & $\begin{array}{l}\text { Students can take exams without any technical } \\
\text { problems }\end{array}$ & 3.52 & 0.74 & 3 & Moderate \\
\hline 24 & $\begin{array}{l}\text { Distance education increases the study burden } \\
\text { for students }\end{array}$ & 3.5 & 0.74 & 4 & Moderate \\
\hline \multirow[t]{2}{*}{22} & All students have easy access to the Internet & 3.42 & 0.85 & 5 & Moderate \\
\hline & $\begin{array}{l}\text { level of distance education application related } \\
\text { to organizational and technical matters }\end{array}$ & 3.63 & 0.65 & & Moderate \\
\hline
\end{tabular}


As it has seen from the above table the total mean for this field was (3.63) and with a standard deviation (0.65), we also note that the question (21) which is "The school's educational platform provides support and assistance for distance education" Ranked first with a mean reached to (4.01) and standard deviation reached to (0.92) and the question (22) which is "All students have easy access to the Internet." with mean reached (3.42) and standard deviation reached (0.85) came in the final rank. This may be attributed to the fact that there are many technical problems in watching lessons at a distance, especially with weak internet speed in some areas, and sometimes even gaps in the digital tools used, and the lack of computers in the home for every student.

Is there a correlation between COVID-19 and the level of distance education application when teaching the social studies curriculum for the upper basic stage?

To determine if there is any relation between COVID-19 and the level of distance education application when teaching the social studies curriculum for the upper basic stage?, Pearson Correlation Test used, which aims to reveal the strength or the degree of relationship between two variables. The degree of relationship between any two variables come between $(+1$ and -1$)$, the more the degree of correlation close to 1 , it means a positive correlation, and the more the degree of correlation close to -1 , it means a negative correlation. To determine the relation is shown in the table (10):

Table (10) Pearson Correlations Coefficients for COVID-19 and the level of distance education application when teaching the social studies curriculum for the upper basic stage $(N=311)$

\section{level of distance education application Coefficients \\ COVID-19}

\begin{tabular}{|c|c|c|}
\hline \multirow{2}{*}{ The level of distance education application related to Teachers } & Pearson Correlation & $.894^{* *}$ \\
\cline { 2 - 3 } & Sig. (2-tailed) & .000 \\
\hline \multirow{2}{*}{\begin{tabular}{c} 
The level of distance education application related to Students \\
\cline { 3 - 3 }
\end{tabular}} & Pearson Correlation & $.585^{* *}$ \\
\hline The level of distance education application related to & Pearson Correlation & .000 \\
\hline organizational and technical matters & Sig. (2-tailed) & $.003^{* *}$ \\
\hline
\end{tabular}

As it has shown from the table (10), there is a significant relation between COVID-19 and the level of distance education application when teaching the social studies curriculum for the upper basic stage, the value of Pearson Correlation is shown in the table and the sig-value was less than the significance level $(\alpha=0.05)$.

For the correlation between COVID-19 and the level of distance education application when teaching the social studies curriculum for the upper basic stage, it's strong with the significance level less than $(\alpha=0.05)$, which means significance relation between and the level of distance education application when teaching the social studies curriculum for the upper basic stage other words COVID-19 have a role in the level of distance education application when teaching the social studies curriculum for the upper 
basic stage". This may be attributed to the fact that the spread of Corona virus prompted the Ministry of Education to use distance learning tools, as officials were quick to take advantage of materials available in the private sector to develop an educational portal called "Darsak" as well as two television channels dedicated to providing lectures on the Internet.

\section{Conclusion and Suggestions}

COVID-19 pandemic imposed a new reality on education. Large numbers of children have stopped attending school or kindergarten, as a result of the preventive measures taken to confront them. This led schools to adopt distance learning led by the teacher.

The present study was made as an attempt to explore the impact of COVID-19 on teaching social studies curriculum in distance education for the upper basic stage from the teachers' Point of view. In light of the results shown in this study, it has been concluded that the Impact of COVID-19 on Teaching Social studies curriculum for the upper basic stage was moderate. Teachers of Social studies curriculum sought to provide students with all the information that they need. Many teachers have attempted to complete their educational mission in communicating information to students using many methods, tools and sites to provide students with the skills and information in the book of national and social education.

The results also showed that the level of applying distance education when teaching the curriculum of social studies to the upper basic stage was also moderate. Distance education is a method of education in communicating information to the students, with the shortest time, less effort, and the greatest benefit. Rundle, Park, Herbstman, Kinsey \& Wang (2020) emphasized that distance education enables the effective management and control of the educational process and effective measurement and evaluation of student performance. The teachers of national and social education resorted to the use of distance education during the crisis of the COVID-19 pandemic to enable students to understand the national and social concepts.

According to the survey results, since the COVID-19 pandemic began to spread widely around the world, it has forced all countries to resort to using the method of distance education to achieve social divergence, with technical and information capabilities varying from one country to another. Hence, the results showed that there is a strong correlation between the spread of the Coruna virus and the use of distance education. The results of the Helmich \& Bloem (2020) showed that distance education contributed to finding logical solutions to the problem of interruption of education in schools, and enabled teachers to reach students easily.

In this study, according to the results obtained, the Ministry of Education should resort to strategic curricula to enable students to receive their education remotely. Besides, some television channels must be used as a ready platform for distance education, and allow teachers to be creative in teaching their 
students. Furthermore, planning for distance learning in a manner that respects the needs of all students and staff.

The results showed that there is a correlation between the COVID-19 and distance education, and this may be due to the spread of the Covid-19 pandemic that prompted the Ministry of Education to rely on technology in the conduct of the educational process and to provide students with new concepts and knowledge. As technology plays a fundamental role in communicating information to students quickly and accurately and contributes to involve all students in the educational process more.

\subsection{Research Limitations and Direction for Further Research}

The human limitation presented a major limitation within this study, as the study population was limited to include Social studies teachers in Jordan, which distributed to them by emails and social media means only. Therefore, this contributed to the decrease of the sample's numbers.

While choosing Social studies teachers were effective and appropriate for the current study, it would have been more effective to incorporate a bigger sample to acquire better outcomes.

Further research into the broader and more extensive of COVID-19 on Teaching Social studies curriculum in Distance Education, regardless of whether they are positive or negative, would be highly valued and appreciated by the researcher.

The current study recommends going beyond the schools' scope and researches higher education from across the entire Hashemite Kingdom of Jordan as a follow-up to this research's findings. Further qualitative research would be needed in the future to accurately assert the level of applying distance education.

\section{References}

- Bozkurt, A., Zawacki-Richter, O., \& Aydin, C. H. (2019). Using social network analysis to review the research in open and distance learning. In Proceedings of the Association for Educational Communications and Technology (AECT) 2019 International Convention (pp. 38-44).

- Burdina, G. M., Krapotkina, I. E., \& Nasyrova, L. G. (2019). Distance Learning in Elementary School Classrooms: An Emerging Framework for Contemporary Practice. International Journal of Instruction, 12(1), 1-16.

- Burgess, S., \& Sievertsen, H. H. (2020). Schools, skills, and learning: The impact of COVID-19 on education. VoxEu. org, 1.

- Cascella, M., Rajnik, M., Cuomo, A., Dulebohn, S. C., \& Di Napoli, R. (2020). Features, evaluation and treatment COVID-19 (COVID-19). In Stat pearls [internet]. Stat Pearls Publishing.

- Chen, X., Ran, L., Liu, Q., Hu, Q., Du, X., \& Tan, X. (2020). Hand Hygiene, Mask-Wearing Behaviors and Its Associated Factors during the COVID-19 Epidemic: A Cross-Sectional Study among Primary School 
Students in Wuhan, China. International journal of environmental research and public health, 17(8), 2893.

- Chugh, R., Ledger, S., \& Shields, R. (2017). Curriculum Design for Distance Education in the Tertiary Sector. Turkish Online Journal of Distance Education, 18(2), 4-15.

- Coibion, O., Gorodnichenko, Y., \& Weber, M. (2020). The Cost of the COVID-19 Crisis: Lockdowns, Macroeconomic Expectations, and Consumer Spending (No. w27141). National Bureau of Economic Research.

- Di Domenico, L., Pullano, G., Sabbatini, C. E., Boëlle, P. Y., \& Colizza, V. (2020). Expected impact of reopening schools after lockdown on COVID-19 epidemic in île-de-France. medRxiv.

- Erickson, M. J., \& Larwin, K. H. (2016). The Potential Impact of Online/Distance Education for Students with Disabilities in Higher Education. International Journal of Evaluation and Research in Education, 5(1), 76-81.

- Gao, X. (2020, May). New Mode of Distance Learning in Primary Schools in the Environment of Multimedia Computer Assisted Instruction. In Journal of Physics: Conference Series (Vol. 1544, No. 1, p. 012031). IOP Publishing.

- Gossenheimer, A. N., Bem, T., Carneiro, M. L. F., \& de Castro, M. S. (2017). Impact of distance education on academic performance in a pharmaceutical care course. PloS one, 12(4).

- Helmich, R. C., \& Bloem, B. R. (2020). The Impact of the COVID-19 Pandemic on Parkinson's Disease: Hidden Sorrows and Emerging Opportunities. Journal of Parkinson's disease, 10(2), 351-354.

- Keeling, M. J., Hollingsworth, T. D., \& Read, J. M. (2020). The Efficacy of Contact Tracing for the Containment of the 2019 Novel COVID-19 (COVID-19). medRxiv.

- Lee, I., Kovarik, C., Tejasvi, T., Pizarro, M., \& Lipoff, J. B. (2020). Telehealth: Helping your patients and practice survive and thrive during the COVID-19 crisis with rapid quality implementation. Journal of the American Academy of Dermatology.

- Madge, C., Breines, M. R., Dalu, M. T. B., Gunter, A., Mittelmeier, J., Prinsloo, P., \& Raghuram, P. (2019). WhatsApp use among African international distance education (IDE) students: Transferring, translating and transforming educational experiences. Learning, Media and Technology, 44(3), 267282.

- McKay, V. I. (2019). Fit for purpose: using a distance education approach to support underperforming schools in South Africa. Progressio, 41(1), 1-26.

- Montacute, R. (2020). Social Mobility and Covid-19: implications of the Covid-19 crisis for educational inequality. Working Paper, The Sutton Trust, UK.

- Petsuwan, S., Pimdee, P., \& Pupat, P. (2019). Strategies for Using the Satellite Distance Education System in Thailand that Affect Student Quality of Marginal Schools in the Lower North Region. Revista ESPACIOS, 40(41). 
- Reimers, F. M., \& Schleicher, A. (2020). A framework to guide an education response to the COVID-19 Pandemic of 2020. OECD. Retrieved April, 14, 2020.

- Rundle, A. G., Park, Y., Herbstman, J. B., Kinsey, E. W., \& Wang, Y. C. (2020). COVID-19-Related School Closings and Risk of Weight Gain Among Children. Obesity.

- Setiawan, A. R. (2020). Scientific Literacy Worksheets for Distance Learning in the Topic of COVID-19 2019 (COVID-19).

- Tavukcu, T., Arapa, I., \& Özcan, D. (2011). General overview on distance education concept. ProcediaSocial and Behavioral Sciences, 15, 3999-4004.

- Topçu, E. (2017). How Do the Teachers Define Social Studies Course?. Journal of Education and eLearning Research, 4(4), 139-153.

- UNESCO. (2020). 290 million students out of school due to COVID-19: UNESCO releases first global numbers and mobilizes response. Retrieved from UNESCO: https://en.unesco.org/news/290-millionstudents-out-school-due-covid-19- unesco-releases-first-

- UNESCO. (2020). COVID-19 Educational Disruption and Response. Retrieved from UNESCO: https://en.unesco.org/covid19/educationresponse

- Zhang, J., Burgos, D., \& Dawson, S. (2019). Advancing open, flexible and distance learning through learning analytics. 40 (3), 303-308. 